\title{
A Case Study of Shoprite Holdings Limited, 2021
}

\author{
Alen Badal \\ Independent Researcher
}

Founded in 1979 in Africa, the vision of Shoprite Holdings Limited has been to offer the lowest prices of groceries. In just over 41 years the company has yielded the notable recognition as Africa's largest grocery retailer. The company has greater than 2,829 stores represented in 15 countries within Africa with the support of over 141,000 associates, which are noted on Table 1. The purpose of this scholarly work is to represent as a teaching case study.

Keywords: strategic management, human resource management, business policy, strategy

\section{COMPANY HISTORY}

In 1979 in the Western Cape, South Africa PEP stores purchased eight stores-Western Cape grocer from the Rogut family, where at the time the grocer had less than 400 employees, with a value of less than R1 million. It was in 1980 where the company decided on the vision to focus on the middle to lower-income all the while of making additional grocery acquisitions. By 1983 the expansion efforts continued to Northern Cape, with the first branch opening in Hartswater, outside of Western Cape.

Success was in the brewing as by 1986 the company listed on the JSE Limited in South Africa with a market capitalization of R29 million. Expansion led to the Free State by opening a location in Bloemfontein, where the company is operating 33 locations throughout various provinces throughout South Africa. The expansion continued across South Africa in 1988 with the opening of two locations in Limpopo, being the first in Polokwane.

In 1990 the pace of expansion accelerated, just after a little over ten years in existence. The company expanded into other regions of Africa by opening a Shoprite in Windhoek, Namibia. Acquisition of Grand Bazaars is made in line with the objective of continuous expansion, where operations existed across 71 store locations and 6,000 associates. Another acquisition was added to the portfolio at the cost of R55 million of Checkers, which was a chain of 169 stores ran by 16,500 associates, yielding 241 outlets and 22,600 associates.

In 1995 the first Shoprite location opened in Central Africa, in Lusaka, Zambia. What also occurred in 1995 was the attainment of Sentra, allowing the group to enter the franchising arena. This provided the opportunity for competition in smaller markets, known as OK Franchise Division. By 1997 expansion efforts continued in Mozambique, by opening the first location in Maputo. The company also acquired OK Bazaars Group, adding 157 super and hyper-sized supermarkets with 146 furniture stores, including OK Furniture and House \& Home. This acquisition represented the company with its first store in Eswatini (Swaziland at the time). In 1998 a supermarket was opened in Botswana. It wasn't until 1999 that MediRite 
was launched within Checkers Hyper location in Brackenfell allowing for customers to fill prescriptions while grocery shopping, marking the launch of the company's supplemental services.

In 2000 the division of Freshmark took place, allowing for fruit and vegetable buying and distribution, adding to the supplementary business division of the company. A first location was opened in Uganda, Shoprite Clock Tower, in Kampala. Interestingly, the company entered Zimbabwe with a store location in Bulawayo Centre, but ceased operations in the county by 2013. Expansion of business into North African market with the opening of seven supermarkets in Egypt ultimately led to pulling out of the market by 2006, citing retailing restrictions. Expansions let to opening a store location in Malawi, by one location opening in Lilongwe.

For a first time, the company decided to market Shoprite and Checkers brands, separately, with Checkers aimed at completing in the middle to higher-income markets. The company continued with acquisitions with Usave in Stellenbosch, in Western Cape, offering a small-store format selling basic foods at lower prices aimed at lower income customers.

By 2002 the company is listed on the Namibian Stock Exchange. In another interesting strategic move the company acquired Score Supermarkets' Tanzanian operations comprising of three supermarkets and a small distribution centre in Dar es Salaam and Arusha only to spin-off the acquisition to a regional retailer, Nakumatt, in 2014, citing the need to focus on investment opportunities elsewhere.

A good investment gone back occurred in Mauritius with the opening of Shoprite Hyper Trianon; however, the business was not continued and the company withdrew from Mauritius in 2018, following a fire at the store. In 2002 five supermarkets along with a distribution centre from a French-owned supermarket group, Champion, in Madagascar. In 2003 continued expansion took place with the opening of Usave in Lilongawe, Malawi; also entered Ghana with the opening of a location in Newton, in the capital city of Accra. The company opened its first Angolan store in Luanda. Additionally, a secondary listing on Lusaka Stock Exchange (LuSE) with 2.7 million shares, at 4,200 Kwacha per share, while the Group's main listing remains on the JSE Limited.

In 2004 the company endeavored with acquiring business wholesale operations in India, franchising their first Shoprite hypermarket in a modern shopping centre in Mumbai; however, creased operating in 2010 citing desires to focus on opportunities in 'commodity-rich' countries in Western Africa. A Usave location was opened in Eswatini (Swaziland at the time).

In 2005 the company entered Nigeria, with a new supermarket in Lagos. It also entered the liquor industry, opening its first Shoprite LiquorShop. This year also involved the acquisition on Computicket and Computicket Travel. Foodworld business was acquired in the Western Cape, a chain that offers Halaal food, constituting 14 stores and four small wholesale outlets to Shoprite's portfolio. Continued expansion of Usave with added locations in Lesotho and Mozambique. In 2008 the company is added to the JSE top 40 index of blue chips, establishing officially Shoprite Holdings as a nationally recognized company. Expansion continued with the adding of Usave in Botswana. Also, Transpharm is acquired and added to the company's growing portfolio of brands, which was a pharmaceutical wholesaler and distribution business of such as toiletries, medical and surgical equipment and veterinary items. Officially, the company became South Africa's largest grocery store chain by market value, being added to the Merrill Lynch \& Co list of most preferred stocks.

Advances continued whereby in 2011 the company acquired Metcash Trading Africa (Pty) Ltd., which included brands Friendly Grocer, 7-Eleven, and Price Club Discount Supermarket. The figure comprised of 150 outlets, growing the company operations to 1,247 stores supported by 95,000 associates. Additional acquisition of Checkers Food Services (CFS) took place, delivering food to the hospitality and catering industry, supporting Shoprite Holdings increasing its ranging from 130 (previous year) to 95 in n Deloitte's Global Powers of Retailing Survey.

By 2012, the company moved up three places to 92nd place, with first place ranking in Africa and the Middle East, in the Global Powers of Retailing list. Also, becoming the first South African retailer to enter the Democratic Republic of Congo (DRC), with a new supermarket location in Gombe, Kinshasa. Also, the company is ranked 11th in the 2013 SA Giants list in Financial Mail's Top Companies and named Deloitte's Global Powers of Retailing largest retailer in Africa and the 93rd biggest in the world! 
The company accelerated expansion following accolades by opening 13 supermarkets across Africa all the while holding its status as Africa and the Middle East's largest retailer according to Deloitte's Global Powers of Retailing survey, holding the 107th largest retailing slot in the world, 41 places ahead of nearest rival.

Fiscal year 2016 was an instrumental year for Shoprite. Namely, improvement strategy efforts resulted in the construction of a mega warehouse locations at Cilmor Distribution Centre in Brackenfell in Western Cape, which consists of three sections: Ambient (operational in August 2017), Frozen and Chilled (operational in 2018) and a new Freshmark Chiller Warehouse covering 30,000 square meters (operational August 2019). Also, opened 30th Shoprite location in Zambia. Consumers surveyed at the end of fiscal 2016 reported 76-percent of South Africa's total adult population, resulting in greater than 29-milion customers, shop at one of the company stores.

In 2017 a first MediRite opens in Maputo, Mozambique, which helped the company gain market-share and grew trading profit 11.6 percent (15.7 percent compared to 52 weeks) to R8 billion. Recognitions continued in 2018 for the company with such as Sunday Times/Sowetan Shopper Survey Grand Prix Award for Overall Best Retailer. Climbing to 62 places its nearest rival on the 2018 Deloitte Global Powers of Retail Report as the 94th biggest retail group in the world. Charging ahead, the company opened its first Shoprite supermarket in Nairobi, Kenya and a first distribution centre in Lagos, Nigeria.

On its 40th anniversary in 2019, the company crept up rankings as the only South African retailer ranked in the top 100 and ranked 86th in the world. A distribution centre opened in Gaborone, Botswana. A first, the company opened K'nect store location in Delft, Cape Town, offering consumers the opportunity to conduct global money transfers, mobile phone purchases, paying for bills, and ticket and insurance purchases. A rewards programme was launched entitled Checkers Xtra Savings Rewards. Checkers offered on-demand grocery delivery in South Africa.

In 2020 the global pandemic Covid-19 troubled the entire world. Shoprite prioritized shopping during the pandemic by introducing virtual grocery vouchers. Purchased electronically and sent to recipient's mobile phone. The focus was to offer contactless transactions at all Shoprite, Usave, Checkers and Checkers Hyper stores. A notable increase in demand resulted in the expansion of Checkers Sixty60 online grocery delivery service.

Bienvenue 2021! What developments should Shoprite Holdings Limited consider implementing in order to continue its success in the grocery retailer industry as the world continues to mitigate Covid-19? Finances have been strong, where Table 2 notes an increased profit for the year in 2020 as compared to 2019.

Simply, Shoprite has pledged to enhance the shopping experience for its customers by offering the likes of Money Market services, where customers can purchase prepaid services, make travel arrangements, pay on accounts, send and receive money. Additionally, the company runs LiquorShops and MediRite Pharmacies, too. Running the many services would not be possible with the support of the many associates. The company recognizes their services and invests in their respective professional futures, whereby many staff have elevated to become leaders making company decisions. The end user of their business is what Shoprite has at the forefront, at all times. The company looks to become flexible with customer needs, while not losing focus of the pledge of offer the lowest prices for goods coupled with unsurpassed customer service. The website of the company is very informative and can be reached at https://www.shoprite.co.za/ for additional details about the company.

\section{Company Brands}

- Supermarkets: Shoprite-flagship brand with approximately 503 stores in South Africa; Checkers, Checkers Hyper-focus on affluent shoppers; Usave-347 locations in South Africa, catering to low-income consumers.

- Liquor Brands: Shoprite LiquorShop and Checkers LiquorShop-500 locations offering national and international alcoholic and non-alcoholic beverages at supermarket prices.

- Furniture Brands: House \& Home-41 store locations in South Africa, selling quality homeware, furniture, electrical appliances to affluent consumers; OK Furniture and Power 
Express-314 store locations selling furniture and electrical appliances to middle-income consumers.

- Pharmaceutical Brands: MediRite Pharmacy-144 pharmacies in South Africa; TransPharmdistribution of pharmaceutical products and surgical equipment across South Africa.

- Ticketing Services: Computicket-located online as well as in-stores of most supermarket and furniture stores servicing entertainment and travel needs ticketing; Computicket Travel-online and in most supermarket and furniture stores servicing ticketing needs of consumers.

- Hospitality: Checkers Food Services- delivery service utilizing 51 fleet for hospitality and catering industries.

- Fruit \& Vegetable Procurement and Distribution: Freshmark-200 locations supplying fresh fruits and vegetables to stores across South Africa as well as other parts of the African continent.

- Financial and Cellular Services: K'nect-9 locations in South Africa, of which the first location opened in 2019, servicing low to middle-class income levels.

- Franchising: OK Franchise Division- 410 store locations servicing all income levels with recognized formats.

- Media Campaign Services: Rainmaker Media-creates campaigns utilizing data gathered.

\section{Strategic Drivers (9)}

The company has prioritized nine (9) strategic drivers categorized under three umbrellas: a smarter Shoprite; closing the gap in key segments; and winning in the long term.

1. A smarter Shoprite: the company aims to ensure customer-first culture with the goal in 2021 to accelerate investment in digital for customers and increase personalization; develop future-fit channels with a goal for 2021 being to grow digital commerce to offer broader merchandising; and enable prevision retailing in 2021 by accelerating investment into building advanced analytics with a focus on price and promotional leadership.

2. Closing the gap in key segments: focus on trusted, profitable private labels in 2021 by product innovation for untapped upmarket shares in Checkers, and Shoprite offering accessible entry price points in the market; grow share in premium food and fresh in 2021 by expansion of Checkers FreshX concept stores and launching an additional 224 fresh product pipeline; a stronger franchise offer in 2021 by rolling-out financial services technology to franchise stores to expand market opportunity.

3. Winning in the long term: assess position in Africa in 2021 by exploring new business models to suit market conditions in each market in order to ensure operation sustainability; refocus capital allocations in 2021 by increasing investments in technology, data and alternative sources of revenue; and unlock alternative revenue in 2021 by accelerating investment in digital to utilize Shoprite as a platform for future streams of revenue. Table 3 notes the financial position with respect to available cash along with Table 4 noting operating profits, which increased in 2020 as compared to 2019. 
TABLE 1

SHOPRITE HOLDINGS LIMITED FOOTPRINT

\begin{tabular}{|c|c|c|}
\hline Country $(n=15)$ & Brand & \# of Locations \\
\hline Ghana & Shoprite & 007 \\
\hline Nigeria & Shoprite & 024 \\
\hline Democratic Republic of Congo & Shoprite & 002 \\
\hline Uganda & Shoprite & 005 \\
\hline Kenya & Shoprite & 002 \\
\hline \multirow[t]{4}{*}{ Angola } & Shoprite & 022 \\
\hline & Usave & 003 \\
\hline & OK Furniture & 011 \\
\hline & Medirite & 001 \\
\hline \multirow{2}{*}{ Zambia } & Shoprite & 038 \\
\hline & OK Furniture & 012 \\
\hline \multirow[t]{5}{*}{ Mozambique } & Shoprite & 015 \\
\hline & Usave & 001 \\
\hline & OK Furniture & 011 \\
\hline & LiquorShop & 001 \\
\hline & Medirite & 001 \\
\hline \multirow[t]{2}{*}{ Malawi } & Shoprite & 004 \\
\hline & Usave & 002 \\
\hline \multirow[t]{5}{*}{ Namibia } & Shoprite & 022 \\
\hline & Checkers & 008 \\
\hline & Usave & 026 \\
\hline & OK Furniture & 018 \\
\hline & OK Franchise Division & 048 \\
\hline \multirow[t]{6}{*}{ Botswana } & Shoprite & 011 \\
\hline & Checkers & 001 \\
\hline & Usave & 004 \\
\hline & OK Furniture & 015 \\
\hline & House \& Home & 001 \\
\hline & LiquorShop & 001 \\
\hline \multirow[t]{4}{*}{ Lesotho } & Shoprite & 007 \\
\hline & Usave & 007 \\
\hline & OK Furniture & 009 \\
\hline & LiquorShop & 003 \\
\hline \multirow[t]{4}{*}{ Eswatini } & Shoprite & 012 \\
\hline & Usave & 006 \\
\hline & OK Furniture & 009 \\
\hline & OK Franchise Division & 008 \\
\hline Madagascar & Shoprite & 010 \\
\hline \multirow[t]{10}{*}{ South Africa } & Shoprite & 514 \\
\hline & Checkers & 227 \\
\hline & Checkers Hyper & 038 \\
\hline & Usave & 386 \\
\hline & OK Furniture & 343 \\
\hline & OK Franchise Division & 362 \\
\hline & House \& Home & 047 \\
\hline & LiquorShop & 517 \\
\hline & Medirite & 157 \\
\hline & K'nect & 007 \\
\hline
\end{tabular}

Source: www.shoprite.co.za 
TABLE 2

\section{STATEMENTS OF COMPREHENSIVE INCOME (SHOPRITE HOLDINGS LTD AND ITS SUBSIDIARIES FOR THE YEAR ENDED 28 JUNE 2020)}

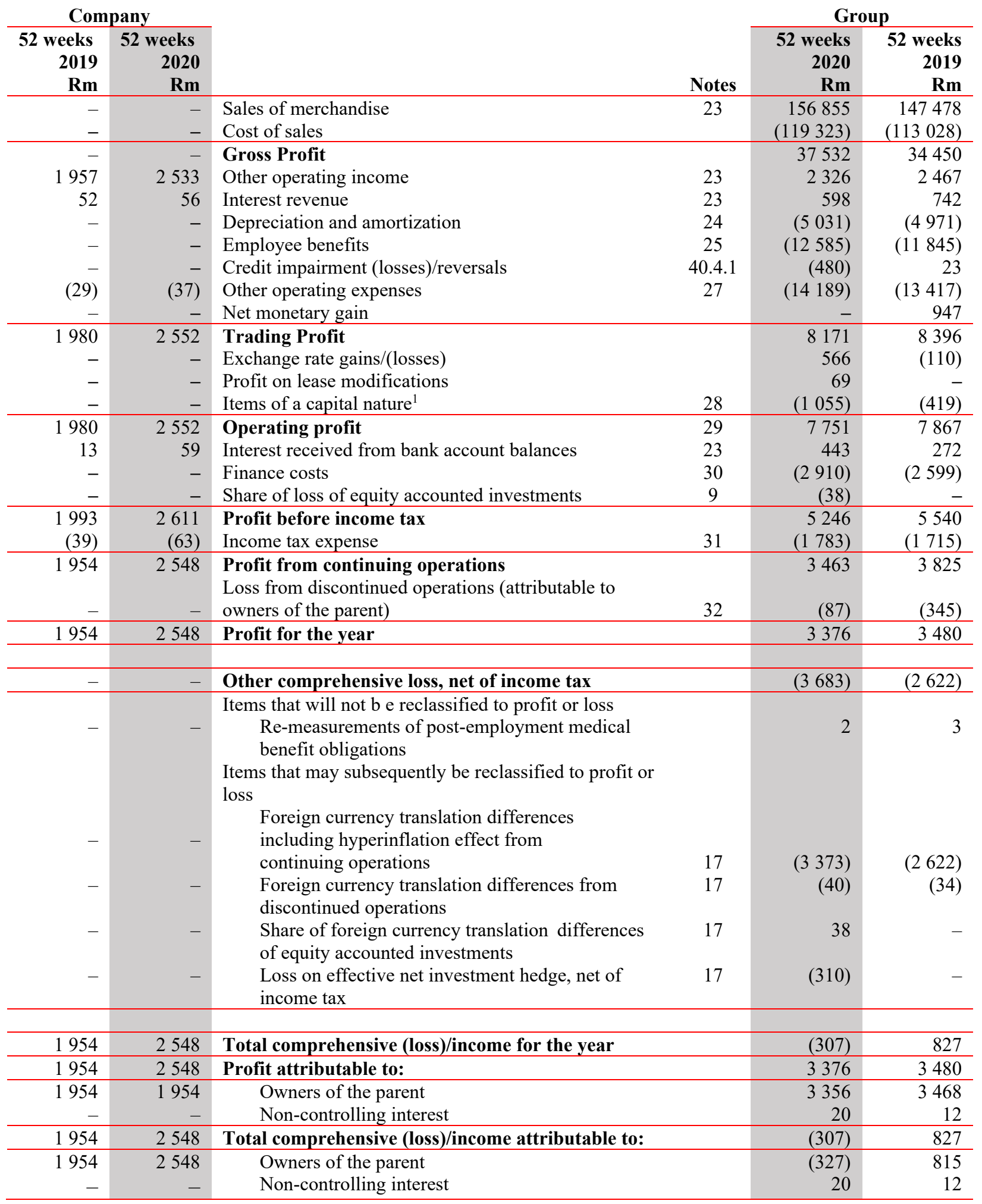




\begin{tabular}{|c|c|c|c|c|c|}
\hline 1954 & 2548 & $\begin{array}{l}\text { Total comprehensive (loss)/income attributable to } \\
\text { owners of the parent arises from: }\end{array}$ & & $(327)$ & 815 \\
\hline 1954 & 2549 & Continuing operations & & $(200)$ & 1194 \\
\hline \multirow[t]{3}{*}{-} & - & Discontinued operations & & $(127)$ & $(379)$ \\
\hline & & $\begin{array}{l}\text { Earnings per share for profit from continuing } \\
\text { operations attributable to owners of the parent: } \\
\text { Basic earnings per share from continuing operations } \\
\text { (cents) }\end{array}$ & 33 & 606.9 & 625.3 \\
\hline & & Diluted earnings per share (cents) & 33 & 606.0 & 624.7 \\
\hline
\end{tabular}

* $\quad$ Restated for the adoption of IFRS 16: Leases and discontinued operations in accordance with IFRS 5 as well as the reclassification of interest revenue previously included in other operating income. Refer to note 42 for details of these changes in accounting policies and note 43 for the reclassification of interest revenue

1. Refer to note 1.1.2 for an explanation of what constitutes items of a capital nature.

\section{STATEMENTS OF FINANCIAL POSITION (SHOPRITE HOLDINGS LTD AND ITS SUBSIDIARIES AS AT 28 JUNE 2020)}

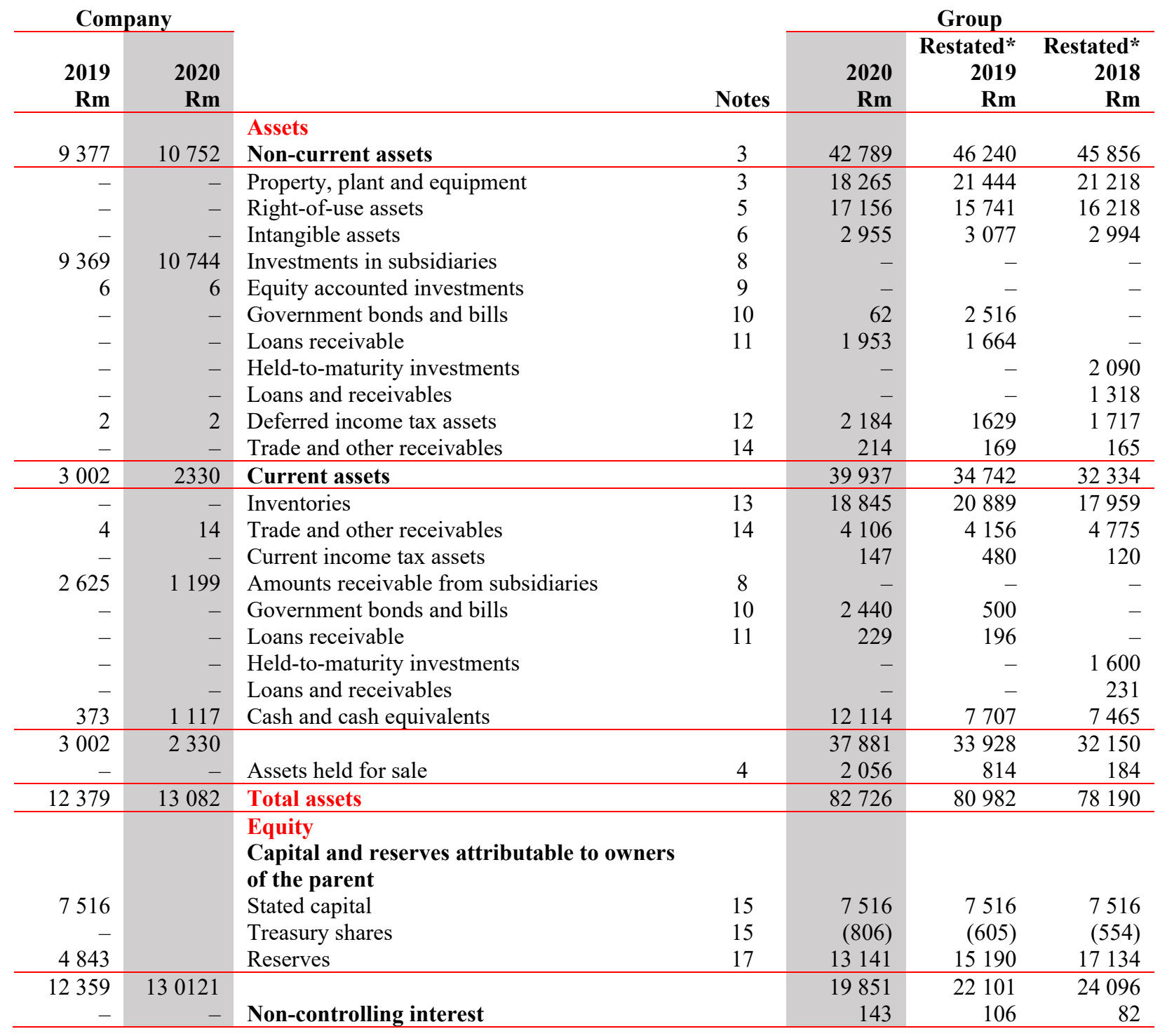




\begin{tabular}{|c|c|c|c|c|c|c|}
\hline 12359 & 13021 & Total equity & & 19994 & 22207 & 24178 \\
\hline- & - & $\begin{array}{l}\text { Liabilities } \\
\text { Non-current liabilities }\end{array}$ & & 30159 & 29019 & 21100 \\
\hline- & - & Lease liabilities & 18 & 20168 & 19158 & 18795 \\
\hline- & - & Borrowings & 19 & 8826 & 9044 & 1371 \\
\hline- & - & Deferred income tax liabilities & 12 & 824 & 538 & 679 \\
\hline- & - & Provisions & 20 & 341 & 279 & 255 \\
\hline 20 & 61 & Current liabilities & & 32573 & 29756 & 32912 \\
\hline 14 & 12 & Trade and other payables & 21 & 20157 & 19325 & 19903 \\
\hline- & - & Contract liabilities & 22 & 864 & 791 & 578 \\
\hline - & - & Lease liabilities & 18 & 3103 & 2320 & 2254 \\
\hline- & - & Borrowings & 19 & 3183 & 2662 & 5606 \\
\hline 6 & 49 & Current income tax liabilities & & 1148 & 423 & 481 \\
\hline- & - & Provisions & 20 & 112 & 111 & 95 \\
\hline- & - & Bank overdrafts & & 2095 & 4124 & 3995 \\
\hline 20 & 61 & & & 30662 & 29756 & 32912 \\
\hline- & - & $\begin{array}{l}\text { Liabilities directly associated with assets } \\
\text { classified as held for sale }\end{array}$ & 32 & 1911 & - & - \\
\hline 20 & 61 & Total liabilities & & 62732 & 58775 & 54012 \\
\hline 12379 & 13082 & Total equity and liabilities & & 82726 & 80982 & 78190 \\
\hline
\end{tabular}

* Restated for the adoption of IFRS 16: Leases. Refer to note 42 for details of this change in accounting policy.

\section{TABLE 4 \\ STATEMENTS OF CASH FLOWS (SHOPRITE HOLDINGS LTD AND ITS SUBSIDIARIES FOR THE YEAR ENDED 28 JUNE 2020)}

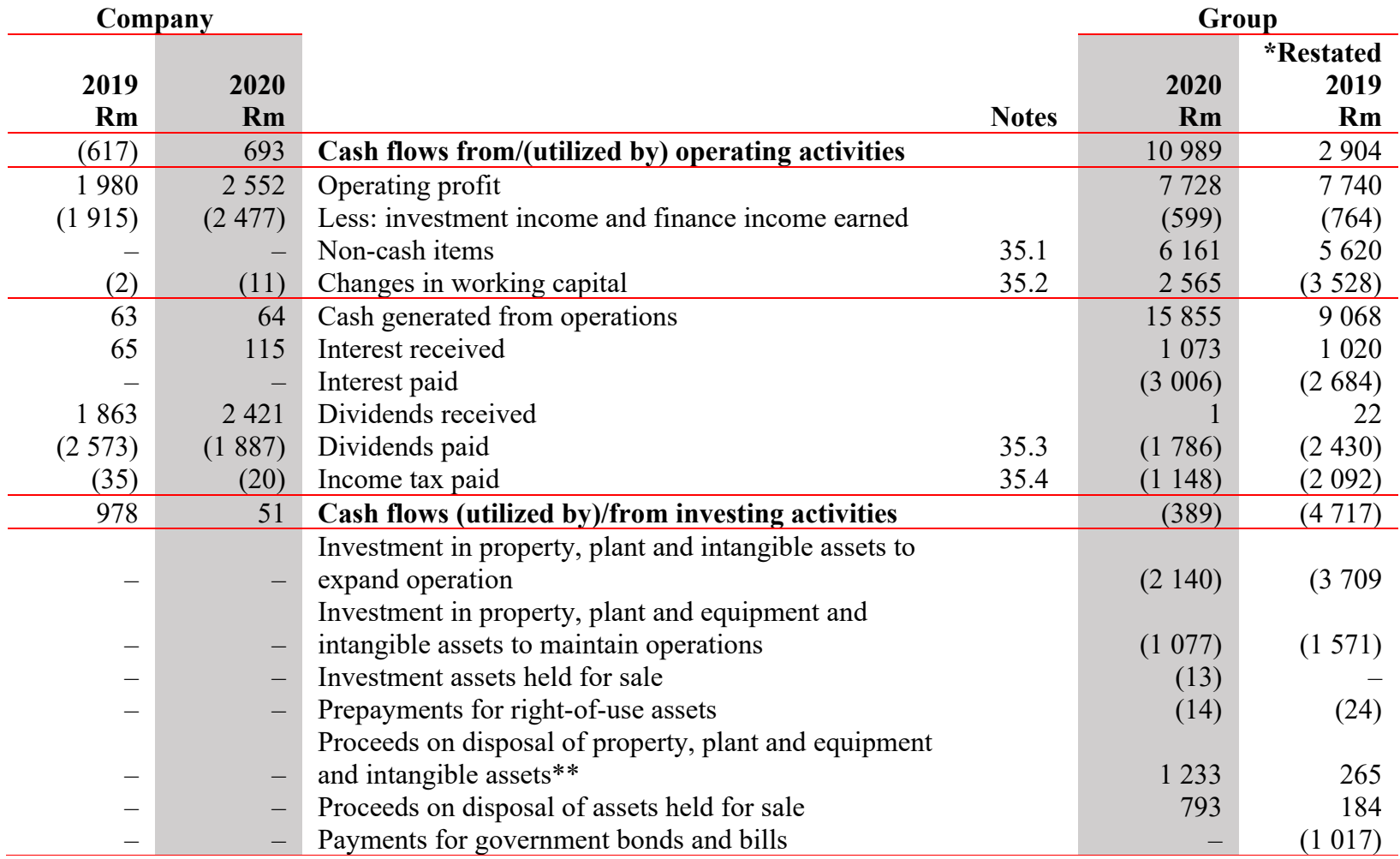




\begin{tabular}{|c|c|c|c|c|c|}
\hline- & - & Proceeds from government bonds and bills & & 924 & 1444 \\
\hline - & - & Loans advanced to Resilient Africa (Pty) Ltd & & (165) & (51) \\
\hline - & - & Other loans receivable advanced & & (208) & (437) \\
\hline- & - & Other loans receivable repaid & & 257 & 204 \\
\hline$(1567)$ & (9 373) & Amounts paid to subsidiaries & & - & - \\
\hline 3040 & 10799 & Amounts received from subsidiaries & & - & - \\
\hline (495) & (1 375) & Investment in subsidiaries & & - & - \\
\hline- & - & Cash inflow on disposal of investment in subsidiary & 35.5 & 36 & - \\
\hline - & - & Acquisition of subsidiaries and operations & & (15) & (5) \\
\hline- & - & Cash flows (utilized by)/from financing activities & & (3 992) & 2152 \\
\hline- & - & Repayment of lease liability obligations & & $(2585)$ & $(2245)$ \\
\hline- & - & Purchase of treasury shares & & $(272)$ & (115) \\
\hline - & - & Proceeds from treasury shares disposed & & 6 & 13 \\
\hline- & - & Repayment of borrowings & & (5 995) & (4 271) \\
\hline- & - & Borrowings raised & & 4854 & 8770 \\
\hline 361 & 744 & Net movement in cash and cash equivalents & & 6608 & 339 \\
\hline 12 & 373 & $\begin{array}{l}\text { Cash and cash equivalents at the beginning of the year } \\
\text { Effect of exchange rate movements and by }\end{array}$ & & 3583 & 3470 \\
\hline - & - & hyperinflation on cash & & $(172)$ & $(226)$ \\
\hline 373 & 1117 & Cash and cash equivalents at the end of the year & & 10019 & 3583 \\
\hline $\begin{array}{r}373 \\
- \\
\end{array}$ & $\begin{array}{r}1117 \\
-\end{array}$ & $\begin{array}{l}\text { Consisting of: } \\
\text { Cash and cash equivalents } \\
\text { Bank overdrafts }\end{array}$ & 40.4.1(d) & $\begin{array}{r}12114 \\
(2095)\end{array}$ & $\begin{array}{r}7707 \\
(4124) \\
\end{array}$ \\
\hline 373 & 1117 & & & 10019 & 3583 \\
\hline
\end{tabular}

\section{Competition \& Direct Global Rivals}

Shoprite Holdings Limited competes with a variety of competitors on a national and international basis. Competitors, such as Amazon and Takealot.com among other online retails also indirectly compete with Shoprite Group. The following key rivals will be discussed: Amazon.com, Takealot.com, Woolworths, Massmart, Pick n Pay, SPAR Group and Carrefour. The main country/market for Shoprite with a strong footprint is South Africa. The company does compete in 14 other countries within the continent of Africa, but not without challenges, which are discussed under industry analysis. The retailing arena is fierce, with constant threats of new and emerging business competing for consumers' business.

\section{Amazon.com (www.amazon.com)}

Founded in 1994 in Bellevue, Washington, which started as selling books, online and expanding to sell virtually everything else. The company was ranked \#2 by Forbes 2020 World's Best Employers survey results. As of 2018, Amazon prime, which is the company's two-day delivery service has been a true success. Stepping-up in time of need, the company increased pay by $\$ 2$ per hour in the U.S.; $\$ 2$ per hour in Canada; $£ 2$ per hour in the UK, and $€ 2$ per hour in many European countries. Additionally, paying double instead of time and a half for any overtime worked, being a minimum of $\$ 34$ per hour. The Whole Foods Market business during the pandemic remained open and serving only seniors during the first hour from opening. The company prioritized stocking and delivery of essential medical needs, while temporarily closing non-essentially selling businesses and providing employees opportunities to work elsewhere within Amazon. Due increased consumer demand, the company had filled 100,000 new positions opened and had to create another 75,000 jobs due to demand.

Amazon realizes the continuous challenges from new entrants in online shopping along with existing respective competitors. The company realizes they may lose business and/or must look to price reductions 
to gain back business, all of which may affect the bottom line, due to constant entrants in the online market place coupled with the ease of comparison shopping around-the-clock for consumers.

One true confession of Amazon is their need to continue with international expansion; however, admitting in certain international terrain they possess little operational experience, which would serve as a weakness in such instances of 'first-to-market' advantages. Additional challenges account for cost related to international expansion and once expanded, establishing consistent profits. Also, external factors related to expansion include governmental regulations, local economic and political challenges and licensing, establishing vendor/supply chain relationships among many others.

\section{Takealot (www.takealot.com)}

Launched in 2011, Takealot.com is the leading ecommerce retailer in South Africa and one of the largest ecommerce innovative retailers on the continent of Africa. Its vision was simple: "To be the largest, simplest, most customer-centric online shopping destination in Africa." It has since opened warehouses in Johannesburg, Durban and Cape Town and expanded produce lines in excess of 21 departments, to include the likes of Electronics, Lifestyle, Media \& Gaming and Fashion. The company has continued in acquisitions, which have led to takealot.com being South Africa's largest ecommerce retailer with over 2000 associates. One limitation is grocery/food; however, the company has acquired MR D Food Division, an on-demand food delivery service.

\section{Woolworths Holdings Limited (www.woolworths.co.za)}

With the first store location opening in 1931 in Cape Town, Woolworths' vision is to be one of the world's most responsible retailers. Approximately $21.1 \%$ of sales derive from fashion, beauty, and home; $2.8 \%$ from financial services; and $76.1 \%$ from food, according to the company's 2020 annual report. In 2020 the company reported R78.3 BN in sales stemming from approximately 1,492 store locations in 14 countries with the help of about 44,862 associates. Woolworths Holdings Limited's (WHL) business portfolio consists of not only Woolworths stores but also retailers David Jones and Country Road Group, where the latter two being an Australian department store and Australian specialty retailer, respectively.

WHL notes a specific need of the group to be successfully navigating the global pandemic effects from Covid-19 in addition to outstanding business fundamentals that have required attention from the group. The group's food business has been very successful, where sales grew by $10.7 \%$.

\section{Massmart (www.massmart.co.za)}

Based in the Republic of South Africa, Massmart, powered by Walmart, operates 420 stores represented in 13 countries in sub-Saharan Africa, through the group's two business units of Massmart wholesale and Massmart retail. Notably, Massmart is the second largest distributor of consumer goods in Africa, while being the leading retailer of general merchandise, liquor and home improvement equipment and supplies and leading wholesaler of basic foods, according to the company.

In 2019 the group reported a 3\% increase in sales in 2019 as compared to 2018, but drastic declines of $<45.1 \%>$ in EBITDA; $<79.3 \%>$ in trading profit before interest and taxation; and $<182.9 \%>$ headline (loss)/earnings. As a result, four (4) key pillars were implemented to help achieve financial goals for the group. The first being restructuring the group operating model-creating an organization structure to optimize serving customers while ensuring market agility and efficiency. The second pillar is portfolio optimization-focus on optimizing store portfolio customer value proposition. The third area is supply chain optimization-with position the supply chain for long-term success. The last being cost reset-to include resetting Massmart's cost base.

\section{Pick n Pay (www.pnp.co.za)}

Established in 1967, Pick n Pay currently has about 1925 store locations (across all formats) in seven countries and 90,000 associates with a turnover of R89.3 billion, according to company annual report, 2020. Pick n Pay stores consist of 1,568, of which 794 are company-owned and 774 are franchised, represented in seven countries. The group also includes Pick n Pay Pharmacy; Boxer; Pick n Pay hypermarkets; Pick n 
Pay Clothing; Pick n Pay Liquor; Pick n Pay Express; Pick n Pay Market stores; Boxer Punch; Boxer Build; Boxer Liquor; and TM Supermarkets.

The majority of the group locations are in South Africa, with 1,771; Lesotho has two; Eswatini with 23; Namibia 38; Botswana 12; Zimbabwe 59; and Zambia 20. The group has noted a future expansion opportunity to be Nigeria.

In 2021 the group noted will focus on the effects of Covid-19 on business. Other areas of concern to focus on are mitigating the impact of currency weakness and hyperinflation; reducing the tax rate; avoid store closures as 30 were closed due to underperforming; and strengthen supply chain labor.

\section{SPAR Group Limited (www.spar.co.za)}

SPAR is a warehousing and distribution operation which serve independent retailers operating under SPAR brand name. The group consists of BWG Group (Ireland \& South West England) with 3 distribution centres 1,391 stores and 3,126 associates. The brands include: Value Centre; EUROSPAR; SPAR express; SPAR; MACE; XL; and Londis. According to 2020 report, this group achieved R29.9 billion in turnover.

SPAR Poland includes two distribution centres and 1,083 associates with 219 retail locations. This group of stores achieved R2.1 billion in turnover under the brands: EUROSPAR; SPAR; Piotr i Pawet; and SPAR express.

SPAR Switzerland has one distribution centre servicing 333 retail stores by 1,423 associates. Turnover was reported of R13.6 billion from the brands: maxi; SPAR; TopCC; and SPAR express.

SPAR Southern Africa, the largest group, has eight distribution centres and 4,527 associates servicing 2,414 retail stores, which achieved a turnover of R78.6 billion from the brands: SUPERSPAR; SPAR express; SPAR SaveMor; Pharmacy at SPAR; SPAR; KWIKSPAR; encore; tops at SPAR!; Built it; and S Buys Group Wholesaler.

\section{Carrefour Group (www.carrefour.com/en/group)}

Carrefour Group is a giant global retailer headquartered in Boulogne-Billancourt, France with over 321,000 associates servicing about 12,225 stores in over 30 countries. The group achieved turnover of almost $€ 80.7$ billion in 2019 , of which over half was generated outside France! The company was founded in 1958 and has been in existence and growing for nearly 62 years. The company reports it gets 1.3 million single visits to all of its online shopping websites, daily.

The largest markets outside of France are Europe, Asia, and South America. A key trait is providing opportunities to the local community it operations when hiring along with giving preference to local supply chains in the region, where approximately $73 \%$ of the food products sold are from local suppliers.

In particular, the group's partner countries it operates in Africa-Middle-East include: Algeria; Armenia; Bahrain; Cameroon; Ivory Coast; Egypt; United Arab Emirates; Georgia; Iraq; Jordan; Kenya; Kuwait; Libya; Morocco; Oman; Uganda; Pakistan; Qatar; Senegal; and Tunisia. It opened its first international store in Italy in 1993 and in China in 1995; then Poland in 1997. By 1999 Carrefour became the world's second largest retailer with 240,000 associates and 9,000 stores. In 2000 it launched the online supermarket, Ooshop. In 2013 it Carrefour joined the CFAO Group to develop varied Carrefour store formats in West and Central Africa.

Cumulatively, the grocery sector in South Africa, if not the entire continent, has both national and international rivals competing for the same customer. While international rivals are limited in comparison to national ones, Carrefour has been utilizing local expertise and supply channels to capture the local consumer. The group has been very successful at utilizing local supply channels and talent to run its business. Shoprite has been growing and is Africa's largest grocery retailer; however, must always be looking both forward at opportunities and in the rear-view mirror at competition.

\section{Food \& Grocery Retail Industry in South Africa (MarketLine Industry Profile, 2020)}

Three key supermarket retailers control much of the grocery retail industry in South Africa. Shoprite Holdings Limited, Pick n Pay Stores Limited, and SPAR (International) are direct rivals with one another, with the leader being Shoprite. The South African food \& grocery retail market yielded total revenues of 
$\$ 49.3$ billion in 2018, which represented an annual compound growth rate of $7 \%$ between fiscal years $2014-$ 2018, according to MarketLine, 2020. Reportedly, the South African economy experienced growth as well by $1.3 \%$ in 2017 and .8 in $2018 .{ }^{1}$ With the global pandemic of Covid-19, the food and grocery industry continued to serve consumers due to being an essential industry. However, according to a Reuters.com report (2020), the pandemic lockdown is expected to hurt profits as grocers, such as Pick n Pay, are prohibited from selling some items, such as liquor, tobacco and clothing, due to restrictions. ${ }^{3}$ Factors, such as unemployment rates and rising household costs were limiting sales, overall, prior to the pandemic. ${ }^{3}$ The pandemic did not help with unemployment rates. With the pandemic brought other external challenges, such as supply chain disruptions and changes in consumer behavior. ${ }^{3}$ The challenge with the restriction of sale of select items is that items, such as tobacco and liquor offer higher profit margins ( $20 \%$ of revenues), so the restructure is survey to affect profits. ${ }^{3}$ All retailers have accrued extra costs associated with hygiene measures, sanitation and staff costs to heed against the spread of Covid-19.

At the conclusion of the lockdown, while Pick n Pay noted an increase in sale items associated with the virus, such as hygiene, cleaning products, non-perishable food items and toilet paper, a negation effect they likely expect is the decline of shopping trips. ${ }^{3}$ Additionally, some reduced or not paid salaries due to the pandemic is expected to dampen sales. ${ }^{3}$ Pick $n$ Pay is looking to save 1 billion rand ( $\$ 54.88$ million) over the next two years by opening smaller stores instead of larger and. ${ }^{3}$ Likely, these challenges are problematic for all retailers and surely to affect everyone due to external factors.

The African Continental Free Trade Area (AfCFTA) is likely to create more international competition for local retailers. Local South African retailers reported seeking strategies to win over South African consumers by offering new financial offerings along with new product lines and store layouts. ${ }^{4}$ Other challenges, such as currency volatility, high import duties and dollar-based rentals created difficulties in markets, such as Angola, Ghana, Kenya, Nigeria and Zimbabwe. ${ }^{4}$ Even the largest retailer, Shoprite, reported struggling business in Angola and Nigeria led to a decline in earnings in 2018 for the first time in two decades; Shoprite announced its exit from Kenya in September 2020, citing failure to secure leases. ${ }^{4}$ Other factors such as movement of goods from ports to stores, oil price volatility and shortage of foreign have led to considerations of either reducing or selling stakes in the Nigerian market. ${ }^{4}$ Other sectors, such as clothing and homeware retailer Mr Price Group has also reported leaving Nigeria; apparel and homeware retailer TFG is leaving Ghana and Kenya. ${ }^{4}$ The South African market is not expected to remain without challenges as the economy is reported to shrink by $8 \%$ in 2020 , according to the International Monetary Fund; unemployment exceeding $30 \%{ }^{4}$

External market challenges had resulted in giant Shoprite Limited Holdings to consider a strategy of expanding mobile financial services via a partnership with Outsurance, selling funeral policies and pet insurance. $^{4}$

Woolworths also withdrew from Ghana in 2019 will look to developing its own beauty brands and consider opening convenience stores; perhaps a good opportunity to grab market share from larger or even smaller rivals during challenging times. ${ }^{4}$ Woolworths is eyeing the opportunity of retailer Edcon, a major South African clothing retailer selling-off to competitors. In the end, it's expected that retailers may experience less challenges once AfCFTA takes effect at the beginning of 2021. ${ }^{4}$ A closure or departure of one business is an opportunity for another. Shoprite's departure from Nairobi (Kenyan Capital) opened the door for a new food mart operated by Naivas, which is Kenya's biggest retailer. ${ }^{4}$ The door is wide open, so perhaps international competition may also be looking to enter Africa; ${ }^{4}$ time will tell.

The economy of South African has been hampered with weakening of the South African rand (currency), drought, rising interest rates, increased fuel and energy costs, and unstable water supply all have affected the economy, but competition among rivals in the industry has contributed to propelling market growth. ${ }^{3}$

Drinks and meat have been the most popular items, with drinks representing $22.9 \%$ of the market's aggregate value in $2018 .^{3}$ The World Bank projects food, beverage and tobacco market to grow $1.7 \%$ in $2020 .^{3}$ Hypermarkets, supermarkets, and hard discounters represent $.594 \%$ of the market share of the food $\&$ grocery industry, with convenience stores and gas stations representing $.224 \%$, in 2018 ; cash and carry 
and warehouse clubs representing .009\%, name and general discounters at $.009 \%$ with other representing $.164 \%$.

While takeaway food options, especially during the pandemic, were utilized in the industry, the cost of such services may limit the dependence of this medium. Food delivery may be one avenue looking ahead as more citizens grow older and transportation may be limited and/or general mobility to visit a grocery store. Healthy eating options may be valued as there has been a growing obesity rate in South Africa; contrary, approximately $27 \%$ of children under the age of five are malnutrition. ${ }^{3}$

Various retailers, such as Pick n Pay, have launched an online distribution centre Gauteng, which helps with efficiency of order processing and deliver. ${ }^{2}$ Amazon is the largest online retailer in South Africa, with reported online sales of \$20.4 million in $2018 .^{2}$ Online sales are expected to rise as the source of point-ofpurchase. The system is open 24/7/365 and allows for the ease of comparison shopping for consumers at the comfort of their home. Google Shopping engine and Amazon are two popular avenues for comparison shopping; ${ }^{2}$ however, sites, such as eBay are often utilized in searches. The cost of running an online business/division is much less costlier than a brick-and-mortar physical location. ${ }^{2}$ Takealot.com is a purse retailer of South Africa and continues to complete in the country, being backed by a marge media and internet investment group, Naspers. ${ }^{2}$

\section{Discussion of Internal \& External Market Factors}

Shoprite has been very successful operating in South Africa, as recognized as the largest retailer in South Africa. The group/company competes with both physical and online retailers in the industry. The proposed Strategic Drivers (9) for 2021 have been prioritized to propel the group/company forward towards additional profits and market share. The drivers are predominantly affecting/controlled by the group/company's internal factors with the exception of a long-term goal of supporting new business models to suit market conditions to ensure operational sustainability. This is very much predicated on external factors affecting the market/industry. Shoprite shall be flexible and attempt to understanding shifts, if any, in market conditions and factors affecting the market. The remaining drives may be influenced by external factors as well. One is the state of the economy and how it may affect any strategy from being funded. The changing wants and needs of consumers are often triggered by external factors, which Shoprite shall consider if wanting to truly place customers first. Same can be true of offering broader merchandising with a focus on price. Often factors (external) affect manufacturing and the entire supply chain, with the final cost being passed onto the retailer and then customer.

Identification of untapped opportunities coupled with welcomed price points in the market is yet another factor not only affected by internal forces, but external as well. Addition of an additional fresh product lines may be predicated by factors outside of Shoprite's control (external). In short, the drivers (9) Shoprite has proposed as business goals for 2021 are affected by internal and external factors, much like many strategies and goals.

\section{Shoprite Holdings Limited in 2021 \& Beyond}

In order to continue increasing profits and navigating additional avenues for market share, CEO Pieter Engelbrecht has identified many areas of focus for 2021 (Strategic Drivers). The business world has been greatly affected in 2020 as a result of the global Covid-19 pandemic to further complex matters. Everything ranging from economic factors, consumer confidence, to supply chain interruptions and operations continue to be challenges for almost every business in the world alike. The world has seen some non-essential businesses cripple and even permanently close. Some citizens have found themselves unemployed and/or experience pay cuts. The level of psychological distress with varying degrees have affected many people in the world. Just how long will it take to overcome the many recent challenges Covid-19 has created in the world no one really knows. What is known is that rebuilding and growing strategies must consider the many recent factors that have resulted as a result of the world pandemic.

Should a company's strategies be focused solely on the effects of the pandemic for 2021? How critical are external strategies, which affect a business, but stem sometimes from factors outside of the direct control of a company? 
Prepare a 3-year strategic plan to help CEO Engelbrecht and Shoprite Holdings Limited overcome threats and capitalize on opportunities. Consider weighing-in on the nine proposed strategic drivers for 2021 and other strategies the company shall consider as well. Prioritize strategies with timelines for implementation and evaluation throughout the lifecycle along with costs and sources for funding.

\section{ENDNOTES}

Sources below, in addition to company websites, were utilized and drawn from for the contents of this teaching case study.

1. MarketLine Industry Profile: Food \& Grocery Retail in South Africa. (2020). Food Retail Industry Profile: South Africa, 1-37.

2. MarketLine Industry Profile: Online Retail in South Africa. (2020). Online Retail Industry Profile: South Africa, 1-56.

3. Dludla, N. (2020, May 12). South Africa's pick n pay sees margin and profit pressure from covid-19 lockdown. Reuters. Retrieved from https://www.reuters.com/article/us-picknpay-results-idUSKBN22O1XP

4. Dludla, N. (2020, November 17). Analysis: After continental retreat, South African retailers strain for profits at home. yahoo!finance. Retrieved from https://finance.yahoo.com/news/analysis-continental-retreat-southafrican-090934697.html 